\title{
PRÁVNICKÁ OSOBA V TRESTNÍM ŘÍZENÍ A STŘET ZÁJMU゚
}

\author{
PAVEL KOTLÁN
}

\begin{abstract}
Legal Person in Criminal Proceedings and Conflict of Interest
The criminal liability of legal person is connected with many problems. The problem of acting on behalf of company in criminal proceedings is very topical especially if the statutory representative is in conflict of interest. The article looks just their conflict of interest if they and their company are in position of accused or a witness. The work tried to offer such an interpretation that takes into account the purpose of criminal proceedings and the right to defense.
\end{abstract}

Keywords: criminal liability; legal person; statutory representative; defense; witness

Klíčová slova: trestní odpovědnost; právnická osoba; statutární zástupce; obhajoba; svědek

DOI: $10.14712 / 23366478.2021 .5$

\section{1. ÚVOD}

S účinností od 1. 1.2012 byla zákonem o trestní odpovědnosti právnických osob (TOPOZ) ${ }^{1}$ zavedena trestní odpovědnost právnické osoby. Od samého počátku je text zákona podroben výrazné kritice, což pramení z nejasnosti mnohých ustanovení i celkového smyslu zákona.

K významným problémům aplikační praxe patř́ situace, kdy fyzická osoba jedná za právnickou osobu v (potenciálním) střetu zájmů. Určit, kdy se konkrétní fyzická osoba ocitá ve střetu zájmů, totiž není jednoduchým problémem a právní úprava § $34 \mathrm{TOPOZ,}$ která střet zájmů mezi fyzickou a právnickou osobou řeší, rozhodně jednoznačnou odpověd’ nedává. Logicky tak $\mathrm{v}$ teoretických úvahách, a tím spíše v praxi, existuje mnoho rozdílných př́stupů. Postupně však dochází k významnému posunu, zejména pod vlivem judikatury Ústavního soudu, z níž je zřejmý trend směřující k potlačení formalismu a $\mathrm{k}$ co nejširšímu uplatnění práva na obhajobu právnické osoby.

Předkládaný text se tak bude snažit odpovědět na otázku, co je podstatou onoho střetu zájmů a jak nejlépe, s ohledem na dikci zákona a jeho smysl, nastalé situace řešit. 1 Zákon č. 418/2011 Sb., o trestní odpovědnosti právnických osob a řízení proti nim, ve znění pozdějších
předpisu. 


\section{JEDNÁNÍ ZA PRÁVNICKOU OSOBU OBECNĚ}

Právnická osoba je umělým výtvorem práva, nadaným právní subjektivitou, ${ }^{2}$ tedy je oprávněna vstupovat do právních vztahů. Jedním ze zásadních ukazatelů ,právního života“ právnické osoby je vymezení právního jednání fyzických osob v právnické osobě angažovaných. $\mathrm{V}$ důsledku rekodifikace soukromého práva, účinné od počátku roku 2014, se prosadila teorie fikce, kdy jednání každé osoby vystupující za právnickou osobou není jednání jejím jménem, tj. př́mým jednáním právnické osoby, nýbrž má charakter zastoupení. ${ }^{3}$ Okruh takových osob je přitom velmi široký, když zahrnuje zákonného zástupce (člena statutárního orgánu, zaměstnance, člena jiného orgánu, zástupce podnikající právnické osoby, vedoucího odštěpného závodu či likvidátora), smluvního zástupce (zmocněnce nebo prokuristu) a opatrovníka (jmenovaného soudem). ${ }^{4}$

Pro námi sledovaný problém je zvláště třeba zdůraznit, že existují specifická pravidla v zákoně o korporacích, která se vztahují k jednání orgánů obchodních společností (viz zejména §§ 44-69 ZOK a speciální ustanovení v rámci určitého typu společnosti). Pokud se totiž podíváme na statistiku odsouzených právnických osob, výrazně v nich dominují (kapitálové) obchodní společnosti, především společnost s ručením omezeným. ${ }^{5}$

Z hlediska soukromoprávní odpovědnosti právnické osoby je klíčové ustanovení $\S 167 \mathrm{OZ}$, podle kterého zavazuje právnickou osobu ,protiprávní čin, kterého se při plněni svých úkoli̊ dopustil člen voleného orgánu, zaměstnanec nebo jiný jeji zástupce vůči třetí osobě“. Trestní odpovědnost se odvíjí od $\S 8 \mathrm{TOPOZ,} \mathrm{v} \mathrm{jehož} \mathrm{důsledku} \mathrm{je}$ právnická osoba $\mathrm{v}$ podstatě trestána za deficit $\mathrm{v}$ kontrolní a rrídící činnosti. ${ }^{6}$

\section{JEDNÁNÍ ZA PRÁVNICKOU OSOBU V ŘÍZENÍ TRESTNÍM}

Oprávnění jednat za právnickou osobu v trestním řízení se podle $\S 34$ odst. 1 TOPOZ primárně odvíjí od právních předpisů upravujících jednání v civilním řízení soudním, tj. od občanského soudního řádu (OSŘ). Ve smyslu § 21 odst. 1 OŠ̌ jedná za právnickou osobu člen/předseda statutárního orgánu, statutárním orgánem pověřený zaměstnanec, vedoucí odštěpného závodu nebo samostatně jednající prokurista. Právnická osoba je v trestním řízení oprávněna zvolit si zmocněnce (§ 34 odst. 2 TOPOZ), který de facto shora zmíněného zákonného zástupce nahradí.

Potud je vůle právnické osoby určit si pro trestní rízení svého zástupce neomezena. Nastane-li ovšem střet zájmů ( $\$ 34$ odst. 4 TOPOZ), musí si právnická osoba určit zástupce jiného. $V$ případě, kdy tak neučiní, a také v případech, kdy nemá , osobu způ-

2 PLECITÝ, V. - SALAČ, J. - BAJURA, J. Úvod do studia občanského práva. Praha: Wolters Kluwer, 2018, s. 72.

3 LAVICKÝ, P. Občanský zákoník I: obecná část (§ 1-654): komentár̆. Praha: C. H. Beck, 2014, s. 835.

4 Tamtéž.

5 K datu 28. 11. 2019 bylo ve veřejné databázi odsouzených právnických osob evidováno 481 odsouzených právnických osob, z nichž bylo 399 s. r. o., 22 a. s. Viz Veřejná evidence odsouzených právnických osob [online]. [cit. 2020-07-20]. Dostupné na: www.justice.cz.

6 Viz Dủvodová zpráva k zákonu č. 418/2011 Sb., komentář k § 8. 
sobilou činit úkony v ř́zeni" nebo ,jejímu zmocněnci nelze prokazatelně doručovat písemnosti“, je ustanoven opatrovník (§ 34 odst. 5 TOPOZ).

Pro úplnost nutno podotknout, že postavení osoby jednající za právnickou osobu v trestním řízení je poněkud netypické. Je-li právnická osoba obviněna, příslušná osoba zmocněnce/zástupce se - jak přiléhavě uvádí Čep ${ }^{7}$ - inkarnuje do postavení obviněné právnické osoby a stává se $\mathrm{v}$ tomto ohledu obviněným, se všemi z toho vyplývajícími právy. $^{8}$

\section{PODSTATA STŘETU ZÁJMU゚}

Nyní se obrat'me ke klíčovému problému: střetu zájmů, který znemožňuje určité fyzické osobě jednat v trestním řízení za osobu právnickou. Idea, aby fyzická osoba, která má konflikt zájmů s právnickou osobou, kterou by měla zastupovat, za ni nejednala, má v zásadě jakýsi preventivní charakter (viz např. § 437 OZ). Vychází tak z náhledu, že možný konflikt zájmů by fyzická osoba mohla řešit ve svůj osobní prospěch, navzdory tomu, že by porušila povinnost jednat vưči právnické osobě s potřebnou loajalitou (viz $§ 159$ odst. $1 \mathrm{OZ}$ ). Obecně přitom lze konstatovat, že zájem právnické osoby musí být jejímu zástupci vždy přednější než jeho vlastní. ${ }^{9}$ To potvrdil i Nejvyšší soud, který konstatoval, že zástupce právnické osoby, co by člen statutárního orgánu, musí upřednostnit zájem akciové společnosti před svým zájmem akcionáře. ${ }^{10}$ Pokud se jedná o střet zájmů v rámci určitého procesu, přidává se $\mathrm{k}$ tomu i ochrana vlastního řízení, tj. aby proběhlo řádně, v souladu s principy, na kterých stojí (viz $§ 21$ odst. 4 OSŘ, $\S 44$ odst. 1 Tř a samožrejmě $\S 34$ odst. 4 TOPOZ).

V trestním řízení proti právnické osobě je střet zájmů definován jako ,úkony v řízení“, které by měla za právnickou osobu vykonat (fyzická) osoba v postavení obviněného, poškozeného nebo svědka. Co ovšem rozumět spojením ,úkony v řízení‘? Obecně lze říci, že se jedná o podmnožinu procesních úkonů, tj. jednání subjektů řízení, ,, které procesní právo předvídá a upravuje a s nimiž spojuje účinky na vznik, změnu nebo zánik procesněprávního vztahu "11 - v daném př́padě tedy jednání fyzické osoby v postavení obviněného/poškozeného/svědka a zároveň v pozici zástupce právnické osoby, které způsobuje vznik/změnu/zánik (trestně)procesněprávního vztahu. V podstatě jsou těmito úkony vlastní práva a povinnosti uplatňovány v řízení (úkony v řízení v užším slova smyslu) - právo zvolit obviněné právnické osobě zmocněnce a právo zvolit jí obhájce. Oproti převládajícímu názoru (vlastně vůbec o tomto polemika neexistuje) mám pochybnost o tom, zda je určení zmocněnce, který by nebyl ve střetu zájmů, oním úkonem

7 GŘIVNA, T. Právo na obhajobu: teorie a praxe 21. století. Plzeň: Vydavatelství a nakladatelství Aleš Čeněk, 2016, s. 166-167.

8 To je ovšem v určitém rozporu se skutečností, že právnická osoba nemůže uskutečnit jednání, které je vyjádřením nebo projevem něčí osobnosti: ,, cannot perform an act, defined as the 'expression or manisfestation of one's personality' “(DUBBER, M. D. - HÖRNLE, T. Criminal law: a comparative approach. Oxford: Oxford University Press, 2014, s. 339).

9 LAVICKÝ, c. d., s. 824.

10 Rozsudek Nejvyššího soudu ČR ze dne 24. 2. 2009, sp. zn. 29 Cdo 3864/2008.

11 Usnesení Nejvyššího soudu ČR ze dne 31. 10. 2012, sp. zn. 33 Cdo 3273/2011. 
v řízení. Změnou osoby, jež se inkarnuje do právnické osoby, se totiž po mém soudu žádný procesněprávní vztah nemění. Připust'me však nyní, že toto užší pojetí pojmu „úkon v řízení“ není prrípadné.

Pokud shora uvedené o střetu zájmů aplikujeme na trestní odpovědnost právnické osoby, mělo by být smyslem ustanovení o střetu zájmů v TOPOZ předejít „,pokušeni““ fyzické osoby řešit konflikt zájmů v trestním řízení na úkor právnické osoby a zajistit rádný průběh řízení zamezením zdvojení procesního postavení svědka/obviněného s postavením zmocněnce - inkarnace (obviněné) právnické osoby.

\section{OBVINĚNÝ VE STŘETU ZÁJMU゚}

Konstrukce trestní odpovědnosti právnické osoby, která co by odpovědnost souběžná a odvozená vychází z konceptu přičitatelnosti, ${ }^{12}$ značně snižuje motivaci obviněného jednat na úkor právnické osoby. ${ }^{13}$ Vina právnické osoby je totiž přímo závislá na vině osoby fyzické. $Z$ originárních znaků skutkové podstaty trestného činu ve vztahu k právnické osobě má význam jen subjektivní stránka - zavinění. ${ }^{14} \mathrm{~V}$ tomto směru tak nemá obviněná fyzická osoba žádnou motivaci jednat v neprospěch právnické osoby, nebot' tím nic nezíská, naopak se vystavuje postihu za porušení loajality, př́padně ohrožuje i svůj majetkový podíl v právnické osobě. Pokud se však týká adhezního řízení, může obviněný usilovat o nevyvinění právnické osoby, aby př́padný výrok o náhradě škody zavazoval solidárně oba. ${ }^{15}$ Zůstává rovněž důvod ochrany řízení spočívající v nutnosti zamezit „dvojjedinosti“" postavení obviněné fyzické osoby a právnické osoby. Opačné názory, a je třeba uvést, že donedávna převažující, vychází z toho, že obviněná fyzická osoba by neměla mít právo určit právnické osobě zmocněnce ani obhájce, protože by takto ,, mohla působit na realizaci procesních práv právnické osoby “.16 Pod vlivem judikatury Ústavního soudu se však situace začíná měnit. Ve smyslu nejnověj-

12 Lze souhlasit s tím, že s ohledem na konotace se soukromoprávním pojetím odpovědnosti právnické osoby a na podstatu trestní odpovědnosti, která je ,, ve skutečnosti kombinací prímého zastoupení a přičitatelnos$t i$ “, by možná bylo namístě ,přičitatelnost“ nahradit „, výstižnějším pojmem ,vytýkatelnost ““ (FENYK, J. Zákon o trestni odpovědnosti právnických osob a ř́zeni proti nim: komentářr. 2. přepr. a dopl. vyd. Praha: Wolters Kluwer, 2018, s. 39-40).

13 Na rozdíl od uplatňování soukromoprávní odpovědnosti, včetně odpovědnosti deliktní, kde míra odpovědnosti fyzické osoby/zástupce je nepř́mo úměrná odpovědnosti právnické osoby. Platí zde Weyrův výrok: ,, [právnické osoby] jsou pouhou umělou konstrukcí, již se má znázorniti omezení individuálni odpovědnosti fysických jednotlivců čili: věta, že ruči (je povinována) právnická osoba, vyjadřuje i negativní pravidlo, že fysičti jednotlivci (jeji členové) neruči resp. nejsou povinováni “ (WEYR, F. - HORÁK, O. Teorie práva. Praha: Wolters Kluwer, 2015, s. 114).

14 Pelc hovoří v této souvislosti o tom, že zavinění právnické osoby ,, originární (vlastní) “ spočívá ,,v opomenutí náležité péče "(PELC, V. Kritika nové metodiky nejvyššího státního zastupitelství k trestní odpovědnosti právnických osob a obrácené důkazní břemeno. In: bulletin-advokacie.cz [online]. 3. 12.2018 [cit. 2020-07-20]. Dostupné na: http://www.bulletin-advokacie.cz/kritika-nove-metodiky-nejvyssiho-statniho -zastupitelstvi-k-trestni-odpovednosti-pravnickych-osob-a-obracene-dukazni-bremeno?browser=mobi).

15 Zde je namístě poznamenat, že vyvinění právnické osoby v situaci, kdy je jí přičítán skutek (člena) statutárního orgánu (tj. situace nejčastější), je málo pravděpodobné, a to s ohledem na to, že je to právě tento statutární orgán, který zavinil onen deficit v rrídící a kontrolní činnosti.

16 GŘIVNA, c. d., s. 169. Podobně JELÍNEK, J. Trestní odpovědnost právnických osob v České republice: problémy a perspektivy. Praha: Leges, 2019, s. 324. 
ších rozhodnutí je apriorní vyloučení obviněného z možnosti zvolit právnické osobě zmocněnce možné jen tehdy, pokud , již takový úkon činí obviněný se záměrem poškodit právnickou osobu v jejím právu na obhajobu či své právo na obhajobu zvýhodnit na její úkor". ${ }^{17}$

Pokud se týká rozsahu pojmu ,úkony v rrízeni“", je - s ohledem na požadavek vyloučení dvojjedinosti - nemožné, aby obviněný činil za právnickou osobu úkony v rrízení v užším slova smyslu. Spornou otázkou zůstává, zda není obviněný oprávněn určit právnické osobě zmocněnce a obhájce. Jistě je možné, že by jím určený zmocněnec ve vztahu ke shora nastíněné náhradě škody, a navzdory riziku porušení loajality, vystupoval na úkor právnické osoby. Ve většině př́ípadů se ovšem kvůli nemožnosti reálného vyvinění právnické osoby, v kombinaci s tím, že ustanovený opatrovník zpravidla nedisponuje informacemi potřebnými $\mathrm{k}$ úspěšné obhajobě, zdá být opatrovnictví pro právnickou osobu horší alternativou než zmocněnec určený obviněným, a tím také jeho realizace nepřiměřeným porušením práva na materiální obhajobu. ${ }^{18}$ Navíc, náleží-li obviněnému většinový obchodní podíl, či dokonce $100 \%$ obchodní podíl společnosti, snadno, prostřednictvím nejvyššího orgánu společnosti, dosadí do statutárního orgánu ,svého člověka“ a ustanovení § 34 odst. 4 TOPOZ tak obejde. ${ }^{19}$ Ostatně Ústavní soud takový postup ani nepovažuje za obcházení zákona, když uvádí, že není vyloučeno, aby obviněná osoba ve střetu zájmů ,učinila kroky potřebné k tomu, aby se okruh osob oprávněných za ni jednat podle § 34 odst. 1 ZTOPO rozrostl o dalši osobu či osoby... ". ${ }^{20} \mathrm{~V}$ důsledku nově vzniklé absence střetu zájmů (mezi novým statutárním orgánem a právnickou osobou) by totiž soud - aby reflektoval zákonnou dikci, že „,opatrovnictví sleduje ochranu zájmi̊ zastoupeného a naplňování jeho práv" - měl zrušit opatrovnictví ${ }^{21}$ a právě nový statutární orgán se tak stane osobou oprávněnou jednat $\mathrm{v}$ trestním řízení za právnickou osobu.

Domnívám se tedy, že významnější argumenty svědčí pro to, aby obviněný měl v př́padě střetu zájmů možnost zásadně si zvolit zmocněnce. $V$ souladu s tím je názor J. Fenyka, který uvádí, že nelze ,, akceptovat postup, kdy orgány činné v trestním řizení odmítnou určeni osoby pro jednání v rámci trestního řizení ze strany obviněného statutárního orgánu a nechají ustanovit opatrovnika. Takový postup je třeba považovat za popřeni práva obviněné právnické osoby na obhajobu a predepsané posloupnosti

17 Nález Ústavního soudu ČR ze dne 21. 1. 2020, sp. zn. IV. ÚS 3139/19. Obdobně: Nález Ústavního soudu ČR ze dne 11.2. 2020, sp. zn. IV. ÚS 3740/19.

$18 \mathrm{~V}$ praxi je přitom stěži dodržován požadavek na osobu opatrovníka vyjádřený Ústavním soudem, tj. že „opatrovnika je pak třeba hledat předevšim v okruhu osob blizkých osobě zastupovaného, resp. těch, jež jsou schopny skutečně reprezentovat zájmy účastnika " (Nález Ústavního soudu ČR ze dne 25. 9. 2002, sp. zn. I. ÚS 559/2000). A jak správně podotýká výše zmíněné rozhodnutí ÚS ČR, sp. zn. IV. ÚS 3139/19, „sama právnická osoba musí mít co nejširši přiležitost uspořádat své záležitosti tak, aby za ni mohla $v$ trestním řizeni vystupovat osoba nejen kvalifikovaná, ale i informovaná o vnitřnich poměrech právnické osoby".

19 Slovenská kodifikace trestní odpovědnosti právnických osob v této souvislosti rozumně určuje výjimku vyloučení osoby ve střetu zájmů, pokud se jedná ,, o jediného člena orgánu právnické osoby anebo o jedinou fyzickou osobu, která tvoři právnickou osobu " (§ 27 odst. 6 zákona o trestnej zodpovednosti právnických osôb č. 91/2016 Z. z.).

20 Nález ÚS ČR, sp. zn. IV. ÚS 3740/19.

${ }^{21} \mathrm{~K}$ tomu viz KUTHANOVÁ, B. Ukončení funkce opatrovníka právnické osoby. In: epravo.cz [online]. 26. 7. 2017 [cit. 2020-07-20]. Dostupné na: https://www.epravo.cz/top/clanky/ukonceni-funkce-opatrovnika -pravnicke-osoby-106183.html. 
úkonů podle $\$ 34$ (čl. 2 odst. 3 Ústavy). ... právo právnické osoby zvolit si zmocněnce má vždy přednost před ustanovením opatrovníka ... pokud se tak právnická osoba rozhodne. "22 Podobně uvádí i Ústavní soud, že volbu zmocněnce obviněnou fyzickou osobou lze ,považovat za neúčinnou pouze tehdy, je-li z konkrétních okolností žrejmé, že jde o zjevné zneužití práva".23

Pokud se týká práva obviněného na formální obhajobu, tj. prostřednictvím obhájce, tak toto je zákazem oprávněnému zástupci právnické osoby určit si obhájce potlačeno. To vynikne zvláště tehdy, je-li tento zákaz - jak se ostatně v praxi děje - uplatňován automaticky. Přitom Ústavní soud (správně) zdůrazňuje, že vyloučit stejného obhájce pro spoluobviněné či pro obviněného a poškozeného, není, s ohledem na mimořádnost zásahu do práva na obhajobu, namístě tehdy, je-li existence kolize zájmů jen potenciální a nevyplývá ,,z konkrétních okolností věci “. ${ }^{24}$ Vztáhneme-li tento názor na určování obhájce právnické osobě při střetu zájmů mezi obviněným a právnickou osobou, nutno dovodit, že obviněnému by nemělo být znemožněno určit obhájce právnické osobě (případně i toho, který zastupuje jeho samotného) minimálně tehdy, není-li střet zájmů, tj. především reálná možnost vyvinění právnické osoby, faktický. Nutno připomenout i profesní odpovědnost advokáta za poskytování právních služeb, která jej nutí vykonávat obhajobu právnické osoby co nejlépe.

Osobně se domnívám, že i právo obviněného zvolit právnické osobě obhájce by mělo platit obecně, a to i s přihlédnutím k tomu, že obviněný může určit právnické osobě i zmocněnce.

Jednoznačně není ve vztahu ke střetu zájmů s právnickou osobou chápán ani samotný pojem „obviněný“. V praxi se k tomuto problému objevuje nejednotný př́istup: od striktního chápání pojmu „obviněný“, tj. vázání střetu zájmů až na okamžik, kdy je fyzické osobě doručeno obvinění, až po názor, že střet zájmů vzniká již vydáním usnesení o zahájení trestního stíhání právnické osoby (opírajícím se o přičtení skutku budoucí obviněné fyzické osoby), tj. kdy vůči fyzické osobě dosud trestní stíhání zahájeno nebylo. První přístup, podpořený primárním doručením usnesení o zahájení trestního stíhání právnické osobě, přitom umožňuje vyhnout se problematickému určení zmocněnce či obhájce budoucím obviněným, nebot' ten dosud v tomto procesním postavení není. Jakousi střední, a v zásadě správnou, cestu představuje názor J. Jelínka, který uvádí, že právnická osoba nemůže činit úkony v řízení po vydání usnesení o zahájení trestního stíhání, je-li v něm zahrnuta fyzická i právnická osoba. ${ }^{25}$

Pokud bychom vycházeli z užšího pojetí pojmu „úkony v řízení“ či neomezovali obviněného v právu zvolit si zmocněnce a obhájce, tak řešení tohoto sporu v zásadě odpadne. S výjimkou uplatnění těchto práv totiž nelze předpokládat, že by až do doručení

22 FENYK, Zákon o trestní odpovédnosti právnických osob a ř́zení proti nim: komentár̆, s. 190. Tento svůj názor pak Fenyk zopakoval a nadále rozvedl, s oporou o novou judikaturu Ústavního soudu, i v: FENYK, J. Obecně oprávněná osoba, zmocněnec a opatrovník v trestním řízení proti právnické osobě a její právo na obhajobu. In: JELÍNEK, J. - FRYŠTÁK, M. - BRUCKNEROVÁ, E. - KALVODOVÁ, V. - FENYK, J. Ochrana základních práv a svobod v trestním řizení. Praha: Leges, 2020, s. 341-344.

23 Nález Ústavního soudu ČR ze dne 23. 6. 2020, sp. zn. I. ÚS 2638/19.

24 Nález Ústavního soudu ČR ze dne 10. 8. 2016, sp. zn. II. ÚS 863/16.

25 JELÍNEK, c. d., s. 322. 
usnesení obviněnému (fyzické osobě), tento činil v řízení nějaké úkony v neprospěch právnické osoby.

\section{POŠKOZENÝ VE STŘETU ZÁJMU゚}

Střet zájmů mezi poškozeným a právnickou osobou je - s ohledem na konstrukci trestní odpovědnosti právnické odpovědnosti - zř́idkavou, téměř paradoxní a v praxi jen obtížně představitelnou situací. ${ }^{26}$ Poškozený je totiž zpravidla statutárním orgánem právnické osoby, kterému je přičítáno jednání některé z osob jednajících za právnickou osobu, tedy nejčastěji právě statutárního orgánu. Jinými slovy, zástupce právnické osoby (v dané věci obviněná fyzická osoba), který je v hierarchii právnické osoby na stejné nebo nižší úrovni než poškozený, poškodil svého nadřízeného nebo partnera. Lze si to představit na př́kladu podvodu, kdy by jeden jednatel s. r. o., který má ve společnosti na starosti obchodní vedení, vylákal na druhém jednateli půjčku pro společnost, ačkoliv by (na rozdíl od něj) věděl, že společnost je ve finančních potížích a půjčku zřejmě nebude schopna vrátit.

Jedná se vlastně o zrcadlově obrácenou situaci, než kterou řeší trestní rád ve vztahu mezi obviněnou fyzickou osobou a poškozeným. Zatímco trestní řád zamezuje obviněnému, aby vykonával oprávnění poškozeného ( $\$ 44$ odst. 1 TŘ), TOPOZ neumožňuje poškozenému jednat za (obviněnou) právnickou osobu. Podobně jako u střetu zájmů právnické osoby a obviněného i zde, při zohlednění hrozby odpovědnosti za porušení svých povinností řádně zastupovat právnickou osobu (které je vystaven zmocněnec i obhájce) na jedné straně a skutečnosti, že zájem poškozeného poškodit právnickou osobu spočívá (obdobně jako u obviněného / fyzické osoby) v zásadě jen ve snaze dosáhnout náhrady škody (i) vůči právnické osobě, na straně druhé, ${ }^{27}$ se jeví správným právo zvolit zmocněnce nebo obhájce právnické osobě poškozenému ponechat.

Rovněž vymezení pojmu poškozený je v otázce střetu zájmů nejasné, což ovšem vyplývá z toho, že nejednoznačně je jeho postavení vymezováno v trestním řádu. ${ }^{28}$ Dikce ustanovení $\S 34$ odst. 4 TOPOZ, tj. postavení pojmu obviněný a poškozený na stejnou úroveň (podobně jako v $\S 65$ odst. 1 TŘ upravujícím nahlížení do spisu), je potvrzením (mého) názoru, že střet zájmů poškozeného se zájmy právnické osoby (podobně jako právo poškozeného nahlížet do spisu) by měl být vázán až na fázi, kdy je zahájeno trestní stíhání. ${ }^{29}$

26 Proto také zůstává zcela stranou zájmu odborných publikací i komentářů.

27 Pokud ovšem poškozený trestným činem má v právnické osobě majetkový podíl, může naopak usilovat o její vyvinění (!), tj. aby k náhradě škody byla povolána jen obviněná fyzická osoba.

28 KOTLÁN, P. Problematické aspekty práv poškozeného v přípravném řízení trestním. In: BENÁK, J. VIKARSKÁ, Z. - JANOVEC, M. (eds.). COFOLA 2018, část VI.: permanentní reforma trestniho řizení (koncepční a nekoncepční změny na půdě trestního práva procesního). Brno: Masarykova univerzita, 2018, s. 79-97.

29 Tamtéž, s. 85-86. Oproti tomu Ústavní soud zastává názor, že je třeba pečlivě zvažovat, zda umožnit poškozenému, resp. osobě činící si nárok na postavení poškozeného, nahlížení do spisu, a to v porovnání ,se skutkovým dějem, jak o něm svědči v dané fázi trestního procesu dostupná zjištěni “. Usnesení Ústavního soudu ze dne 9. 6. 2008, sp. zn. I. ÚS 1587/07. 


\section{SVĚDEK VE STŘETU ZÁJMU゚}

Střet zájmů svědka s právnickou osobou spočívá v zamezení zmíněné (nežádoucí) dvojjedinosti procesního postavení. Byt' tedy nelze z procesního postavení svědka nijak dovozovat motivaci k poškození právnické osoby, je zřejmé, že dvojjedinost není možné připustit. Jedná-li se však o právo zvolit zmocněnce a obhájce, stěží lze jakýkoliv konflikt identifikovat. Proto není důvod svědka v tomto směru, pokud samožrejmě nefiguruje zároveň $\mathrm{v}$ postavení poškozeného, ${ }^{30} \mathrm{v}$ právu na formální obhajobu (tj. určit právnické osobě zmocněnce) i materiální obhajobu (tj. určit obhájce) omezovat. Nehledě $k$ tomu, že zmocněním neadekvátní osoby by tento svědek nedodržel svou povinnost loajality ( $\$ 159$ odst. $1 \mathrm{OZ}$ ). Porušení povinnosti řádné péče a odpovědnost za náhradu škody totiž dopadá i na situaci, kdy k určitým úkonům člen voleného orgánu (neadekvátní) osobu zmocní. ${ }^{31}$

Rovněž je vhodné podotknout, že se v praxi objevuje zneužití tohoto institutu, kdy jsou všichni členové statutárního orgánu vyslechnuti jako svědci, byt' nemají o podstatě prrípadu žádnou povědomost, ,čímž se vytvoři predpoklady pro ustanoveni opatrovníka “.32 Podobně od Unie obhájců se objevuje kritika předvolání všech oprávněných zástupců za svědky, nebot’ to údajně vede k tomu, že ,obviněné právnické osobě je opatrovnik de facto oktrojován ".33

Ve vztahu k právu zvolit si obhájce potvrzuje můj postoj vyjádření Ústavního soudu, když uvádí, že ,, sice lze z dikce § 34 odst. 4 ZTOPO dovodit, že za obviněnou právnickou osobu nemůže obhájce zvolit osoba, která je v téže věci svědkem, avšak z hlediska účelu by na tyto prípady právní úprava dopadat nemèla. Tato úprava totiž řeši problematiku střetu zájmů mezi obviněnou právnickou osobou a těmi, kdo za ni jednají, přičemž k takovému střetu zájmů nedocházi při volbè obhájce právnické osobè ze strany svědka. Proto je třeba ustanoveni § 34 odst. 4 ZTOPO interpretovat úžeji a na uvedené př́pady jej neaplikovat. "34 Pokud přijmeme tento názor, pak postrádá logiku neumožnit svědkovi zvolit právnické osobě i zmocněnce, a to s ohledem na již u obviněného charakterizovanou paradoxní situaci, kdy by byl ustanoven opatrovník soudem, avšak obhájce zástupcem právnické osoby. Unie obhájců v souladu s tím zastává názor, že „, ustanoveni § 34 odst. 4 ZTOPO musí být restriktivně vykládáno v tom smyslu, že osoba, která je svědkem v téže věci (v trestním řizení proti právnické osobě), není zbavena práva určit, kdo bude v trestním ř́zení za obviněnou právnickou osobu činit úkony ". ${ }^{35}$ $\mathrm{V}$ této souvislosti upozorňuje na př́stup praxe, kdy je často ,,opatrovníkem ustanovena

30 Pak by přirozeně bylo třeba aplikovat i to, co bylo řečeno k poškozenému ve střetu zájmů.

31 LAVICKÝ, c. d., s. 824-825.

32 FENYK, Zákon o trestni odpovédnosti právnických osob a řizení proti nim: komentár̆, s. 191.

33 Stanovisko Unie obhájců č. 2/2019 k institutu opatrovníka právnické osoby v trestním řízení [online]. 6. 3. 2019 [cit. 2020-07-20]. Dostupné na: https://www.uocr.cz/stanoviska/stanovisko-unie-obhajcu -c-2-2019-k-institutu-opatrovnika-pravnicke-osoby-v-trestnim-rizeni/.

34 Nález Ústavního soudu ČR ze dne 15. 8. 2018, sp. zn. II. ÚS 131/18; podobně i Nález Ústavního soudu ČR ze dne 20. 11. 2018, sp. zn. I. ÚS 2436/18.

35 Stanovisko Unie obhájců ČR č. 1/2017 k otázce práva na obhajobu obviněných právnických osob a jednání za ně [online]. 23. 3. 2017 [cit. 2020-07-20]. Dostupné na: https://www.uocr.cz/stanoviska/stanovisko -unie-obhajcu-cr-c-1-2017-k-otazce-prava-na-obhajobu-obvinenych-pravnickych-osob-a-jednani-za-ne/. 
osoba, která nemá s chodem společnosti žádné zkušenosti, na jejím fungování není nijak zainteresována a její zájmy v trestním ř́zeni hájí pouze formálně " 36

$\mathrm{S}$ ohledem na to, že i u svědka se střet zájmů týká úkonů v řízení v užším slova smyslu, je vhodné definici svědka v $§ 34$ odst. 4 TOPOZ vykládat v návaznosti na procesní situaci, kdy má být daná osoba, podle názoru orgánu činného v trestním řízení (tj. v zásadě policejního orgánu v přípravném řízení či soudu v řízení před soudem), vyslechnuta jako svědek či s ní má být prováděn jiný úkon v tomto postavení. Nejčastěji se tak bude jednat o převzetí předvolání $\mathrm{k}$ výslechu svědka.

V rámci vyšetřování by však mohla vzniknout paradoxní situace, kdy by za obviněnou právnickou osobu byla vyslýchána fyzická osoba, která by zároveň byla vyzvána k podání vysvětlení (jako potenciální svědek). ${ }^{37}$ Za účelem ochrany řádného průběhu a smysluplnosti trestního řízení by pak zde bylo namístě vztáhnout pojem ,svědek“ i na osobu podávající vysvětlení, co by svědka potenciálního. Otázkou ovšem je, zda by takto nemohlo docházet ke zneužívání, ve shora naznačeném směru, tedy v neprospěch právnické osoby a jejího práva na materiální obhajobu. Nejkorektnější se tak jeví ve vyšetřování institut podání vysvětlení vůči zástupci právnické osoby nevyužívat. Ostatně, pokud výsledky prověřování postačovaly k zahájení trestního stíhání, verifikační funkce př́ipravného řízení byla splněna a dotyčného může, $v$ př́ípadě potřeby, vyslechnout jako svědka soud.

\section{ZÁVĚR}

Střet zájmů právnické osoby v trestním řízení a osoby za ni jednající, resp. zamezení tomuto střetu, je určováno zejména ideou ochrany práv právnické osoby a ochranou trestního řízení před zdvojováním procesního postavení jedné osoby. Z analýzy jednotlivých situací se jeví jako nejsprávnější intepretace, která umožňuje obviněnému, poškozenému i svědkovi ve střetu zájmů určit právnické osobě zmocněnce i obhájce, a tak, bez zásadnějšího ohrožení práv právnické osoby, dodržet požadavek na materiální a formální obhajobu. ${ }^{38}$ Právě taková interpretace je v souladu se závazným principem zohlednění účelu právních norem (tj. účel právní normy v § 34 odst. 4 TOPOZ), ${ }^{39}$ který je nutno v prŕpadě rovnocenných výkladových variant upřednostnit.

Lze s povděkem kvitovat, že judikatura Ústavního soudu je v zásadě v souladu s naznačeným směrem. To by mělo vést $\mathrm{k}$ tomu, že praxe orgánů činných v trestním řízení bude daleko více reflektovat právo na obhajobu právnických osob.

36 Tamtéž.

37 Podotýkám, že ve smyslu § 164 odst. 1 TŘ policejní orgán i ve vyšetřování vyslýchá potenciální svědky formou úředního záznamu o podání vysvětlení, nikoliv jako svědky formou protokolu o výslechu svědka.

38 Na problém vymezení střetu zájmů v § 34 odst. 4 TOPOZ lze nahlížet - jak učinil Ústavní soud ve zmíněném nálezu sp. zn. II. ÚS 131/18 ve vztahu k určení obhájce svědkem - jako na problém nadbytečnosti právní úpravy a jeho řešení tzv. teleologickou redukcí. Nutno ovšem podotknout, že pak se nejedná o interpretaci, nýbrž o nalézání práva, které odůvodňuje najít právo mimo rozsah pojmu. K tomu viz MELZER, F. Metodologie nalézání práva: úvod do právní argumentace. 2. vyd. Praha: C. H. Beck, 2011, s. 103.

39 WINTR, J. Metody a zásady interpretace práva. Praha: Auditorium, 2013, s. 129. 
Přesto by, de lege ferenda, bylo vhodné obsah ustanovení § 34 odst. 4 TOPOZ upřesnit, aby byl jeho dosah jednoznačnější, popř. i doplnit ustanovením o právu jiných osob zainteresovaných v právnické osobě zmocněnce a obhájce určit. ${ }^{40}$ Každopádně by bylo vhodné navázat vyloučení poškozeného/obviněného/svědka z úkonů $\mathrm{v}$ trestním řízení za právnickou osobu v $§ 34$ odst. $4 \mathrm{TOPOZ}$ výslovně na termín „střet zájmư“.

JUDr. Mgr. Pavel Kotlán, Ph.D.

Vysoká škola PRIGO

pavel.kotlan@prigo.cz

ORCID: 0000-0001-9946-1955

$40 \mathrm{~K}$ tomu viz např. GŘIVNA, c. d., s. 172-173. 